\title{
Peran kepercayaan merek sebagai variabel mediasi pada hubungan kepribadian merek halal dan loyalitas merek
}

\author{
Mirza Putri Andita* \\ Fakultas Ekonomi Program Ilmu Manajemen Universitas Sriwijaya \\ Jl. Masjid Al Ghazali, Bukit Lama, Kec. Ilir Bar. I, Kota Palembang, Sumatera Selatan, \\ 30128, Indonesia \\ mirzaputriandita@gmail.com \\ Sulastri Sulastri \\ Fakultas Ekonomi Program Ilmu Manajemen Universitas Sriwijaya \\ J1. Masjid Al Ghazali, Bukit Lama, Kec. Ilir Bar. I, Kota Palembang, Sumatera Selatan, \\ 30128, Indonesia \\ sulastri@unsri.ac.id

\section{Zakaria Wahab} \\ Fakultas Ekonomi Program Ilmu Manajemen Universitas Sriwijaya \\ J1. Masjid Al Ghazali, Bukit Lama, Kec. Ilir Bar. I, Kota Palembang, Sumatera Selatan, \\ 30128, Indonesia \\ zkwahab@yahoo.com \\ *Penulis Korespondensi
}

Submitted: Oct 12, 2021; Reviewed: Oct 19, 2021; Accepted: Nov 5, 2021

\begin{abstract}
Customer loyalty is currently becoming one of the crucial things for the company to survive in competitive markets. Globalization causes imported cosmetic products from global brands can enter other countries' markets easily. Nowadays imported cosmetic brands from other countries such as USA, South Korea, and Japan come and take a huge of Indonesia's skincare market share. This change becomes threat for local cosmetics brands in Indonesia such as Wardah. This study was conducted to analyzes whether halal brand personality affects brand loyalty. This study also analyzes whether brand trust can mediate the relationship between halal brand personality and brand loyalty. The sampling method used in the study is non-probability sampling with snowball technique. The data in this research were obtained by distributing an online questionnaire to 111 respondents who were Wardah's face skincare consumers and had shopped at least twice in the last 1 year (January 2020-July 2021). The data of this study were analyzed using Structural Equation Modeling method with SmartPlS 3 software. The results of this study indicate that halal brand personality has positive and significant effect on brand loyalty, brand trust has positive and significant effect on brand loyalty, and brand trust successfully mediates the relationship between halal brand personality and brand loyalty. This study provides new insight which suggests marketers develop branding strategies in order to strengthen brand trust which leads to maintaining customer loyalty.
\end{abstract}

Keywords: brand loyalty; brand trust; halal brand personality

Abstrak: Loyalitas pelanggan saat ini menjadi aspek penting bagi perusahaan untuk bertahan di pasar yang kompetitif. Globalisasi menyebabkan produk impor dari merek global dapat masuk ke pasar DOI: https://doi.org/10.28932/jmm.v21i1.4066 
negara lain dengan mudah. Saat ini ada banyak merek kosmetik impor yang masuk dan mengambil sebagian besar dari pangsa pasar kosmetik skincare Indonesia. Perubahan ini menjadi ancaman bagi merek kosmetik lokal seperti Wardah. Penelitian ini bertujuan untuk menganalisis apakah kepribadian merek halal berpengaruh terhadap loyalitas merek. Penelitian ini dilakukan untuk menganalisis apakah kepribadian merek halal berpengaruh terhadap loyalitas merek. Penelitian ini juga menganalisis apakah kepercayaan merek dapat mengatur hubungan antara kepribadian merek halal dan loyalitas merek. Metode pengambilan sampel yang digunakan di penelitian ini ialah non-probability sampling dengan menggunakan teknik snowball sampling. Data yang digunakan dalam penelitian ini diperoleh dengan menyebarkan kuesioner online kepada 111 responden yang merupakan konsumen produk perawatan kulit wajah Wardah dan sudah pernah berbelanja minimal 2 kali dalam 1 tahun terakhir (Januari 2020-Juli 2021). Analisis data menggunakan SmartPLS 3 dan menggunakan pemodelan persamaan struktural (SEM). Hasil penelitian ini menunjukkan bahwa kepribadian merek halal secara langsung berpengaruh positif dan signifikan terhadap loyalitas merek, kepercayaan merek secara langsung berpengaruh positif dan signifikan terhadap loyalitas merek, serta kepercayaan merek mampu memediasi hubungan kepribadian merek halal dan loyalitas merek. Penelitian ini memberikan wawasan baru yang menyarankan pemasar mengembangkan strategi branding yang dapat memperkuat kepercayaan konsumen terhadap merek halal untuk mempertahankan loyalitas konsumen.

Kata kunci: kepercayaan merek; kepribadian merek halal; loyalitas merek

\section{PENDAHULUAN}

Loyalitas merek adalah salah satu tujuan yang ingin dicapai pemasar dalam branding saat ini. Mudahnya merek global masuk ke pasar Indonesia disebabkan oleh adanya globalisasi, membuat merek lokal terancam kehilangan pangsa pasarnya (Lina, 2020). Keadaan ini membuat pemasar merek lokal di Indonesia berfokus kepada pembentukan loyalitas merek. Loyalitas merek mengacu pada tingkat preferensi konsumen untuk merek tertentu, yang ditandai dengan tingkat pembelian kembali dan tingkat pemahaman konsumen tentang informasi dan peristiwa merek tertentu dan konsumen setia lainnya dari merek tersebut (Keller, 2013). Pemasar percaya bahwa dengan mempertahankan pelanggan setia, mereka dapat mengurangi biaya hingga lima kali lipat daripada menemukan pelanggan baru (Delgado \& Alemán, 2001; Nikhashemi \& Valaei, 2018). Hal ini dikarenakan konsumen yang setia dengan merek lebih mudah untuk membeli kembali, tidak terlalu memperhatikan merek dari pesaing, serta berpeluang besar untuk merekomendasikan merek (Kotler \& Armstrong, 2009). Menurut Keller (2013), loyalitas merek tercermin dari keterikatan sikap dan loyalitas perilaku konsumen. Pada tahap keterikatan sikap, konsumen sudah memiliki sikap positif yang membuat merek menjadi unik baginya seperti mengatakan merek menjadi salah satu favoritnya atau mengganggap merek sebagai "sedikit tekanan" yang mereka harapkan. Loyalitas perilaku menunjukkan bahwa konsumen dianggap loyal lewat seringnya repurchase serta perilaku loyal lainnya, seperti merekomendasikan merek kepada kerabat sekitar dengan sukarela.

Islamic branding menjadi faktor penting dalam pembentukan loyalitas konsumen Indonesia terhadap merek tertentu. Merek halal ialah merek yang proses pembuatan produknya mematuhi Syariat Islam (Ismail \& Alias, 2016). Kebanyakan merek diakui sebagai merek halal saat produknya telah berhasil mendapat predikat halal dari lembaga sertifikasi halal tertentu (Lada et al., 2009). Mayoritas masyarakat Indonesia ialah muslim yang taat, sehingga mereka cenderung memperhatikan kehalalan saat melakukan pembelian produk (Pew Research Center, 2020). Pentingnya aspek kehalalan bagi konsumen Indonesia juga terlihat dari tingginya permintaan akan produk halal, sehingga menyebabkan cakupan pasar halal juga meluas. Produk halal saat ini bukan sekedar makanan dan minuman saja, tetapi juga mencakup barang dan jasa seperti kosmetik (Katadata, 2020). Kosmetik dapat dikatakan halal jika bahan bakunya alami dan aman digunakan serta proses produksinya, mulai dari pembuatan sampai ke tahapan pengemasannya, sesuai dengan syariat Islam dengan tidak menyakiti makhluk hidup (Paragon Technology and Innovation, 2018). Hal ini penting untuk diperhatikan oleh produsen kosmetik halal saat proses produksi, agar mereka dapat menciptakan produk berkualitas tinggi yang tidak akan menimbulkan efek samping bagi penggunanya.

Penanaman karakter yang ada dalam konsep kepribadian merek halal ke dalam merek halal dapat membentuk loyalitas konsumen Indonesia. Kepribadian merek halal ialah sekumpulan karakteristik manusia ideal yang diajarkan oleh hukum Islam yang diasosiasikan dengan merek halal (Aaker, 1991; 
Ahmed \& Jan, 2015). Konsep kepribadian merek halal mengesankan bahwa merek tersebut mampu menjamin kebutuhan yang dicari konsumen muslim dalam suatu merek produk (Ahmad, 2015). Merek menggunakan branding Islam serta yang proses pembuatannya sesuai dengan hukum islam disebut sebagai merek halal (Ismail \& Alias, 2016). Selain itu, penanaman karakter ini juga mempermudah terciptanya hubungan erat antara konsumen dan merek lewat kesamaan karakter (Nikhashemi \& Valaei, 2018). Kesamaan karakter merek dengan konsumen ini bisa berupa actual self konsumen maupun ideal self yang diinginkan ada pada diri konsumen tersebut (Ahmed \& Jan, 2015; Belk, 1988; Malhotra, 1988). Ahmad (2015) menjelaskan ada 5 dimensi karakter dalam kepribadian merek halal, yaitu purity (kesucian), excitement (kegembiraan), safety (keamanan), sophistication (kecanggihan), dan righteousness (kebaikan). Penelitian ini hanya fokus membahas satu karakter saja yaitu kebajikan, karena fokus penelitian ini ialah cara merek halal membentuk loyalitas konsumen lewat aktivitas corporate social responsibility (CSR). Karakter kebajikan berperan penting dalam meyakinkan konsumen. Hal ini dikarenakan oleh kemampuan karakter ini dalam menawarkan kenyamanan psikologis kepada konsumen saat berinteraksi dengan merek (Zainudin et al., 2019). Perasaan aman yang dirasakan konsumen saat berinteraksi dengan merek memunculkan kepercayaan konsumen terhadap merek (Delgado \& Fernández, 2016; Fernandez \& Lewis, 2019). Kepercayaan terhadap merek merupakan modal penting untuk membangun loyalitas jangka panjang konsumen (Geçti \& Zengin, 2013).

Kepercayaan merek menjadi penentu utama dari loyalitas konsumen (Mabkhot et al., 2017). Hal ini dikarenakan kepercayaan menciptakan hubungan bernilai tinggi antara merek dan konsumen (Kuleh \& Setyadi, 2016; Morgan \& Hunt, 1994). Kepercayaan konsumen muncul saat konsumen merasa bahwa merek bertanggung jawab dengan klaim atau janji merek yang berguna bagi kesejahteraan konsumen (Delgado \& Fernández, 2016). Shin et al. (2019) menjelaskan bahwa kepercayaan konsumen diukur dengan melihat kredibilitas merek yang didefinisikan sebagai seberapa besar konsumen bergantung pada kemampuan merek dalam menjalankan fungsi yang dinyatakannya.

Wardah merupakan merek kosmetik yang branding-nya menggunakan konsep kepribadian merek halal. Penanaman kepribadian merek halal dalam Wardah terlihat lewat CSR. Wardah mengadakan kampanye sosial di Indonesia, seperti Wardah Inspiring Movement (WIM) yang membantu mengatasi masalah pendidikan, kesehatan, pemberdayaan perempuan, dan lingkungan di Indonesia (Paragon Technology and Innovation, 2018). Kesuksesan branding Wardah ini dapat terlihat dari banyaknya produknya yang meraih Top Brand dari lembaga Top Brand Award. Namun, untuk kategori posisi produk skincare wajah, Wardah masih jauh tertinggal dari market leader skincare wajah, yaitu Pond's. Perbandingan persentase produk-produk skincare wajah Wardah dan Pond's di Top Brand Award disajikan dalam tabel berikut.

Tabel 1. Produk skincare wajah Wardah dan Pond's di Top Brand Award index tahun 2020

\begin{tabular}{lrr}
\hline \multicolumn{1}{c}{ Kategori Produk } & \multicolumn{2}{c}{ Merek } \\
& Wardah & Pond's \\
\hline Sabun pembersih wajah & $5,8 \%$ (peringkat 5) & $22,4 \%$ (peringkat 1) \\
Pelembab wajah & $19,6 \%$ (peringkat 2) & $21,4 \%$ (peringkat 1) \\
Anti aging & $2,5 \%$ (peringkat 5) & $35,4 \%$ (peringkat 1) \\
Sun care & $12,3 \%$ (peringkat 4) & $3,4 \%$ (peringkat 5) \\
\hline
\end{tabular}

Sumber: Top Brand Award (2020)

Studi sebelumnya yang membahas dampak kepercayaan merek terhadap loyalitas merek menunjukkan hasil yang konsisten. Melewar et al. (2017) menemukan kepercayaan konsumen yang baik terhadap suatu perusahaan menyebabkan konsumen tersebut loyal terhadap perusahaan. Penemuan Lestari et al. (2018) juga menjelaskan bahwa terdapat hubungan positif antara kepercayaan merek dengan loyalitas konsumen. Raut et al. (2019) juga menemukan bahwa kepercayaan kepada merek memengaruhi loyalitas konsumen terhadap merek tersebut.

Beberapa penelitian terdahulu yang meneliti tentang hubungan antara kepribadian merek halal dengan kepercayaan merek menemukan hasil yang berbeda-beda. Penemuan Tong et al. (2018) juga menjelaskan bahwa kepribadian merek berpengaruh terhadap kepercayaan merek. Namun, Lin (2010) menemukan adanya beberapa karakter dalam kepribadian merek yang tidak berpengaruh signifikan 
terhadap loyalitas merek. Selain itu, Lin (2010) juga menjelaskan adanya konsumen yang tidak terikat secara emosional dengan merek namun tetap melakukan repurchase dikarenakan oleh faktor-faktor lain saat pembelian berlangsung.

Penelitian terdahulu yang mengkaji tentang pengaruh kepribadian merek halal terhadap loyalitas merek menemukan hasil yang berbeda. Penemuan Tubagus \& Tumbuan (2018) menjelaskan bahwa kepribadian merek memengaruhi loyalitas konsumen untuk membeli kembali produk dari kosmetik halal. Utari et al. (2017) juga menemukan pengaruh yang signifikan dari kepribadian merek terhadap kepercayaan merek yang pada akhirnya juga meningkatkan loyalitas konsumen. Namun, Zainudin et al. (2019) juga menemukan karakter keamanan dalam konsep kepribadian merek halal (kegembiraan, kecanggihan, dan kebenaran) tidak memiliki dampak signifikan terhadap loyalitas merek.

Adanya perbedaan di dalam hasil penelitian yang dilakukan sebelumnya memunculkan pertanyaan apakah kepribadian merek halal yang telah diterapkan dalam branding Wardah memiliki pengaruh terhadap loyalitas konsumen serta apakah kepercayaan merek mampu meningkatkan pengaruh kepribadian merek terhadap loyalitas merek. Oleh karena itu, penelitian ini bertujuan untuk menganalisis apakah variabel kepribadian merek halal secara langsung, maupun melalui variabel kepercayaan merek, berpengaruh terhadap loyalitas merek. Hipotesis dari penelitian ini dapat dijabarkan seperti berikut ini.

H1: Kepribadian merek halal berpengaruh signifikan terhadap loyalitas merek .

H2: Kepribadian merek halal berpengaruh signifikan terhadap kepercayaan merek.

H3: Kepercayaan merek berpengaruh signifikan terhadap loyalitas merek.

H4: Kepercayaan merek memediasi hubungan antara kepribadian merek halal dan loyalitas konsumen.

\section{METODE}

Data dalam penelitian ini didapatkan dari pengisian kuesioner online oleh responden penelitian ini. Kuesioner terdiri dari pertanyaan yang berkaitan dengan data pribadi profil orang yang diwawancarai dan pernyataan yang terdiri dari indikator variabel. Pernyataan angket menggunakan skala Likert, dengan bobot 1-5.

Populasi dalam penelitian ini ialah wanita Indonesia yang merupakan pengguna skincare wajah Wardah. Besarnya populasi yang akan diteliti membuat peneliti mengambil sampel. Sampel dalam penelitian ini ialah wanita muslimah yang tinggal di 5 kota besar di Indonesia (Palembang, Jakarta, Lampung, Bandung, dan Malang) yang telah melakukan pembelian produk perawatan kulit wajah Wardah minimal 2 kali dalam satu tahun terakhir (Januari 2020-Juli 2021). Metode pengambilan sampel penelitian menggunakan teknik snowball sampling, yaitu teknik pengambilan sampel yang berpindah dari satu responden ke responden lainnya melalui proses rolling. Pendistribusian kuesioner dilakukan pada bulan Juli 2021. Jumlah sampel yang digunakan ialah 105 orang responden. Karakteristik narasumber penelitian ini dijelaskan di Tabel 2 .

Tabel 2. Karakteristik responden

\begin{tabular}{llrr}
\hline Variabel & Kategori & Jumlah & Persentase \\
\hline Jenis kelamin & Pria & 0 & 0 \\
& Wanita & 105 & 100 \\
\hline Usia & $\leq 30$ tahun & 85 & 80,95 \\
& 31-50 tahun & 17 & 16,19 \\
& $>$ 50 tahun & 3 & 2,86 \\
\hline Jenjang & $\leq$ SMA & 18 & 17,14 \\
pendidikan & S1 sederajat & 70 & 66,67 \\
& $>$ S1 & 17 & 16,19 \\
\hline Pendapatan & 1 Juta Rupiah & 28 & 26,67 \\
per bulan & 1-5 Juta Rupiah & 60 & 57,14 \\
& $>$ 5 Juta Rupiah & 17 & 16,19 \\
\hline Domisili & Palembang & 80 & 76,19 \\
& Lampung & 4 & 3,80 \\
& Jakarta & 11 & 10,48 \\
& Bandung & 7 & 6,67 \\
\hline
\end{tabular}




\begin{tabular}{rrr}
\hline Malang & 3 & 2,86 \\
\hline
\end{tabular}

Sumber: Hasil pengolahan aplikasi Excel (2021)

Penelitian ini menggunakan tiga variabel, yaitu kepribadian merek halal, kepercayaan merek, dan loyalitas merek. Definisi operasional variabel dan indikator variabel dijabarkan pada Tabel 3.

Tabel 3. Definisi operasional variabel dan indikator

\begin{tabular}{|c|c|c|c|c|}
\hline No. & Variabel & Definisi Operasional & Indikator & Sumber \\
\hline 1 & $\begin{array}{l}\text { Kepribadian } \\
\text { merek halal }\left(\mathrm{X}_{1}\right)\end{array}$ & $\begin{array}{l}\text { Pemberian karakter ke } \\
\text { merek untuk menguatkan } \\
\text { branding-nya sebagai } \\
\text { merek halal. }\end{array}$ & $\begin{array}{l}\text { - Memberi motivasi } \\
\text { - Mengedukasi masalah } \\
\text { spiritual agama } \\
\text { - Menebar manfaat kepada } \\
\text { masyarakat lewat kegiatannya }\end{array}$ & $\begin{array}{l}\text { Ahmad } \\
(2015)\end{array}$ \\
\hline 2 & $\begin{array}{l}\text { Kepercayaan } \\
\text { merek (Y) }\end{array}$ & $\begin{array}{l}\text { Keyakinan konsumen } \\
\text { pada kemampuan merek } \\
\text { untuk memenuhi } \\
\text { ekspetasinya. }\end{array}$ & $\begin{array}{l}\text { - Terlihat meyakinkan } \\
\text { - Merek dapat diandalkan } \\
\text { - Sesuai dengan klaimnya }\end{array}$ & $\begin{array}{l}\text { Shin et al. } \\
\text { (2019) }\end{array}$ \\
\hline 3 & $\begin{array}{l}\text { Loyalitas } \\
\text { merek (Y) }\end{array}$ & $\begin{array}{l}\text { Keterikatan emosional } \\
\text { disertai dorongan untuk } \\
\text { berperilaku positif kepada } \\
\text { merek halal. }\end{array}$ & $\begin{array}{l}\text { - Menjadi pilihan utama } \\
\text { - Aktif mengikuti info terbaru } \\
\text { merek } \\
\text { - Merekomendasikan } \\
\text { - Melakukan repurchase }\end{array}$ & $\begin{array}{l}\text { Kotler \& } \\
\text { Armstrong } \\
\text { (2009) }\end{array}$ \\
\hline
\end{tabular}

Sumber: Olahan aneka sumber (2021)

Kuesioner online dalam penelitian ini harus lulus uji validitas dan uji reliabilitas terlebih dahulu untuk memastikan alat penelitian valid dan reliable dalam mengukur indikator variabel (Ferdinand, 2014). Dengan bantuan software SmartPLS 3, uji validitas dan uji reliabilitas menggunakan confirmatory factor analysis (CFA). Analisis data dalam penelitian ini menggunakan pemodelan persamaan struktural (SEM).

\section{HASIL DAN PEMBAHASAN}

\subsection{Hasil uji validitas dan uji reliabilitas}

Tujuan dari uji validitas dari alat penelitian ialah untuk mengetahui apakah alat penelitian telah memenuhi syarat convergent validity. Tahapan pertama dalam uji convergent validity ialah dengan melihat nilai output outer loading. Apabila factor loading indikator $>0,5$, maka indikator variabel tersebut masih dianggap valid (Ghozali, 2014). Hasil uji convergent validity penelitian ini dijabarkan pada Tabel 4.

Tabel 4. Hasil convergent validity

\begin{tabular}{|c|c|c|}
\hline Indikator Variabel & Nilai Factor Loading & Keterangan \\
\hline KMH1 & 0,832 & Valid \\
\hline KMH2 & 0,806 & Valid \\
\hline KMH3 & 0,803 & Valid \\
\hline KM1 & 0,830 & Valid \\
\hline KM2 & 0,822 & Valid \\
\hline KM3 & 0,854 & Valid \\
\hline LM1 & 0,815 & Valid \\
\hline LM2 & 0,755 & Valid \\
\hline LM3 & 0,844 & Valid \\
\hline LM4 & 0,726 & Valid \\
\hline
\end{tabular}

Sumber: Hasil pengolahan aplikasi SMART PLS (2021) 
Hasil olah data pada Tabel 4 menunjukkan bahwa semua nilai factor loading lebih dari 0,5. Hal ini menunjukkan semua indikator penelitian ini valid. Berikut ini ialah path diagram variabel dalam penelitian ini.

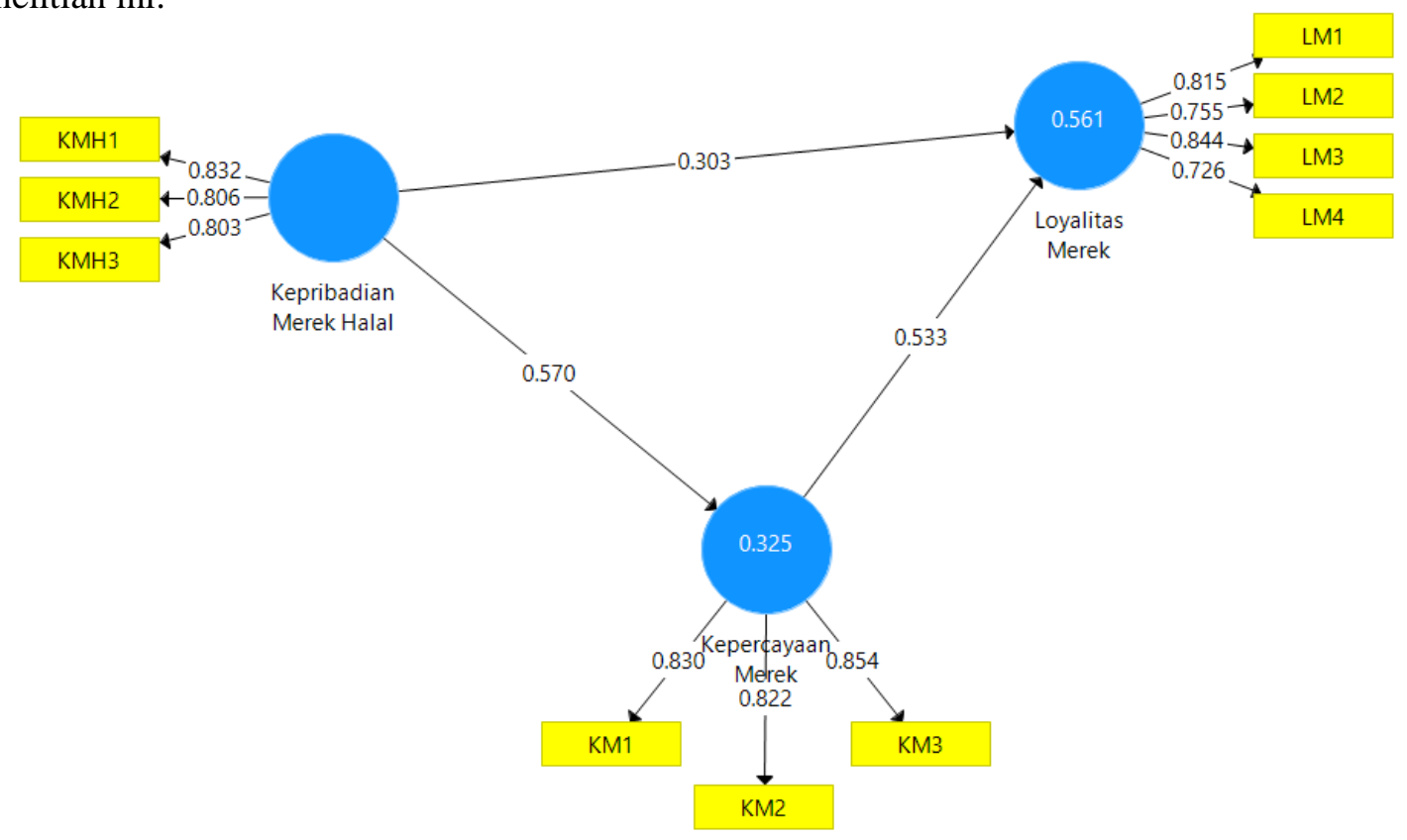

Gambar 1. Path diagram

Sumber: Hasil pengolahan aplikasi SMART PLS (2021)

Selain melihat nilai factor loading dari setiap konstruk, melihat nilai Average Variance Extracted (AVE) juga menjadi tahapan selanjutnya dari uji validitas di PLS. Parameter dari nilai AVE ialah di atas 0,5. Tabel 5 menyajikan hasil nilai AVE setiap konstruk di penelitian ini.

Tabel 5. Hasil nilai AVE

\begin{tabular}{lcc}
\multicolumn{1}{c}{ Konstruk } & AVE score & Keterangan \\
\hline Kepribadian merek halal & 0,662 & Valid \\
Kepercayaan merek & 0,698 & Valid \\
Loyalitas merek & 0,618 & Valid \\
\hline
\end{tabular}

Sumber: Hasil pengolahan aplikasi SMART PLS (2021)

Tabel 5 hasilnya menampilkan bahwa seluruh nilai $A V E>0,50$. Hal ini menunjukkan bahwa setiap indikator valid. Hasil ini menunjukkan bahwa alat penelitian yang digunakan memenuhi persyaratan convergent validity. Pengujian reliabilitas alat penelitian dilakukan dengan melihat nilai Cronbach's alpha dan composite reliability. Jika nilai Cronbach's alpha masing-masing konstruk > 0,6 serta nilai composite reliability konstruk $>0,7$, maka konstruk dianggap memiliki tingkat reliabilitas yang tinggi (Abdillah \& Jogiyanto, 2015). Hasil uji reliabilitas penelitian ini tercantum pada Tabel 6 di bawah ini.

Tabel 6. Hasil uji reliabilitas

\begin{tabular}{lccc}
\multicolumn{1}{c}{ Variabel/ Iindikator } & Cronbach Alpha & Composite Reliability & Keterangan \\
\hline Kepribadian merek halal & 0,745 & 0,750 & Reliabel \\
Kepercayaan merek & 0,783 & 0,785 & Reliabel \\
Loyalitas merek & 0,793 & 0,800 & Reliabel \\
\hline
\end{tabular}

Sumber: Hasil pengolahan aplikasi SMART PLS (2021)

Hasil yang ditampilkan Tabel 6 menunjukkan bahwa nilai cronbach's alpha setiap konstruk > 0,6 serta nilai composite reliability setiap konstruk juga $>0,7$. Hal ini menunjukkan bahwa alat penelitian reliabel. 


\subsection{Hasil uji evaluasi model struktural (inner model)}

Tujuan dari uji model struktur adalah untuk memeriksa apakah model struktur yang dibangun sudah baik dan akurat. Evaluasi model struktural diuji dengan melihat nilai $R$ Square, nilai $\mathrm{Q}^{2}$, dan nilai goodness of fit. Koefisien determinasi yang disebut nilai $R$ Square menjelaskan perubahan nilai konstruk dependen. Nilai $R$ square terbagi menjadi tiga kategori, yaitu $R$ Square kuat (nilai $\mathrm{R}>0,67), R$ Square moderat/ sedang (nilai $\mathrm{R}>0,33$ ), dan $R$ Square lemah (nilai $\mathrm{R}>0,19$ ) (Chin, 1998; Ghozali, 2014). Hasil nilai $R$ Square ditunjukkan Tabel 7.

Tabel 7. Nilai $R$ square

\begin{tabular}{lc}
\hline \multicolumn{1}{c}{ Variabel } & $R$ Square \\
\hline Kepercayaan merek & 0,325 \\
Loyalitas merek & 0,561 \\
\hline
\end{tabular}

Sumber: Hasil pengolahan aplikasi SMART PLS (2021)

Hasil pada Tabel 7 menunjukkan bahwa varians variabel kepercayaan merek adalah 32,5\%, yang berarti bahwa 67,5\% lainnya dijelaskan oleh faktor lain yang tidak diteliti dalam penelitian ini, sedangkan varians variabel loyalitas merek ialah $56,1 \%$, yang berarti bahwa $43,9 \%$ lainnya dijelaskan oleh variabel yang tidak diteliti dalam penelitian ini. Langkah selanjutnya adalah melihat nilai $\mathrm{Q}^{2}$, yang mengukur kualitas pengamatan dan estimasi parameter yang dihasilkan oleh model penelitian. Menurut Henseler (2018), jika nilai $\mathrm{Q}^{2}>0$, maka model tersebut layak dan memiliki nilai prediksi yang relevan. Rumus perhitungan $\mathrm{Q}^{2}$ adalah:

$$
\begin{aligned}
\mathrm{Q}^{2} & =1-\left(1-\mathrm{R}^{2} 1\right)\left(1-\mathrm{R}^{2} 2\right) \\
& =1-(1-0,325)(1-0,561) \\
& =1-0,296 \\
& =0,704
\end{aligned}
$$

Hasil perhitungan ini menunjukkan $\mathrm{Q}^{2}>$ nol, sehingga disimpulkan bahwa model struktural yang diajukan sudah relevan. Langkah selanjutnya ialah pengujian goodness of fit. Uji goodness of fit akan dilakukan dengan perhitungan manual dengan rumus sebagai berikut.

$\mathrm{GoF}=\sqrt{ } \mathrm{AVE} \times \mathrm{R}^{2}$

$\mathrm{GoF}=\sqrt{ } 0,66 \times 0,704$

$\mathrm{GoF}=0,572$

Hasil perhitungan GoF ini ialah 0,572, yang berarti masuk ke dalam kategori GoF besar (Tenenhaus \& Vinzi, 2004). Maka dari itu, dapat disimpulkan bahwa model penelitian ini baik dan akurat.

\subsection{Hasil uji hipotesis}

\begin{tabular}{|c|c|c|c|c|}
\hline Variabel & Original Sample & $t$-statistic & $P$ values & Keterangan \\
\hline $\begin{array}{l}\text { Kepribadian merek halal > Loyalitas } \\
\text { merek }\end{array}$ & 0,303 & 4,026 & 0,000 & Diterima \\
\hline $\begin{array}{l}\text { Kepribadian merek halal > } \\
\text { Kepercavaan merek }\end{array}$ & 0,570 & 9,108 & 0,000 & Diterima \\
\hline Kepercayaan merek > Loyalitas merek & 0,533 & 7,183 & 0,000 & Diterima \\
\hline $\begin{array}{l}\text { Kepribadian merek halal > } \\
\text { Kepercayaan merek > Loyalitas merek }\end{array}$ & 0,304 & 5,322 & 0,000 & Diterima \\
\hline
\end{tabular}

Uji hipotesis dilihat dari nilai statistik t. Hipotesis dapat diterima apabila t-statistik > nilai t-tabel sebesar 1,96 atau nilai signifikansi $<0,05$. Hasil uji hipotesis ditunjukkan pada Tabel 8 .

Tabel 8. Hasil uji hipotesis

Sumber: Hasil pengolahan aplikasi SMART PLS (2021)

Hasil uji hipotesis yang disajikan pada Tabel 8 menunjukkan kepribadian merek halal berpengaruh positif dan signifikan terhadap loyalitas merek. Temuan ini dibuktikan dengan nilai t-statistik sebesar 4,026 (t-statistik $>1,96)$ dan nilai $P$ sebesar $0,000(P<0,05)$. Hal ini menunjukkan bahwa semakin tinggi branding Wardah dengan konsep kepribadian merek halal, maka semakin tinggi pula loyalitas 
merek. Hasil penelitian ini juga mendukung temuan Tubagus \& Tumbuan (2018) serta Borzooei \& Asgari (2013) yang menjelaskan kepribadian merek halal memengaruhi loyalitas konsumen untuk membeli kembali produk serta adanya keterikatan emosional terhadap merek halal.

Hasil uji hipotesis pada Tabel 8 menunjukkan bahwa kepribadian merek halal berpengaruh positif dan signifikan terhadap kepercayaan merek. Temuan ini dibuktikan dengan nilai t-statistik $>1,96$, yaitu 9,108 , serta nilai $P<0,05$, yaitu 0,000 . Hal ini menunjukkan bahwa peningkatan kepribadian merek halal juga mengarah pada peningkatan kepercayaan konsumen terhadap merek Wardah. Hasil ini mendukung hasil penelitian Tong et al. (2018) dan Shin et al. (2019) yang menjelaskan kepribadian merek halal berpengaruh signifikan pada kepercayaan konsumen terhadap merek.

Hasil uji hipotesis yang disajikan pada Tabel 8 menunjukkan kepercayaan merek berpengaruh positif dan signifikan terhadap loyalitas merek. Temuan ini dapat dibuktikan dengan nilai t-statistik sebesar 7,183 (t-statistik > 1,96) dan nilai $P$ sebesar 0,000 $(\mathrm{P}<0,05)$. Hal ini menunjukkan bahwa peningkatan kepercayaan terhadap merek Wardah menyebabkan peningkatan pada loyalitas konsumen Wardah juga. Hasil ini selaras dengan studi yang dilakukan oleh Raut et al. (2019) dan Sánchez et al. (2020) yang menjelaskan kepercayaan merek berpengaruh signifikan pada loyalitas konsumen terhadap merek.

Hasil uji hipotesis di Tabel 8 menunjukkan bahwa kepercayaan merek memainkan peran variabel perantara antara kepribadian merek halal dan loyalitas merek. Temuan ini dapat dibuktikan dengan nilai t-statistik $>1,96$, yaitu 5,322, serta nilai $P<0,05$, yaitu 0,000. Hasil ini menunjukkan kepribadian merek halal berpengaruh positif dan signifikan terhadap kepercayaan merek, yang selanjutnya memengaruhi loyalitas konsumen terhadap Wardah.

\section{SIMPULAN DAN SARAN}

Penelitian ini membuktikan bahwa kegiatan menebar manfaat kepada masyarakat Indonesia menjadi indikator yang paling besar dalam pembentuk kepribadian merek halal, sedangkan indikator pembentuk terbesar kepercayaan merek ialah kesesuaian klaim merek dengan nilai manfaat yang dirasakan konsumen. Penelitian ini menemukan bahwa kepercayaan merek mampu memediasi hubungan antara kepribadian merek halal dan loyalitas. Dari nilai original sample yang diperoleh dalam penelitian ini, dapat disimpulkan bahwa pengaruh langsung kepribadian merek halal terhadap loyalitas merek tidak sebesar saat dimediasi oleh kepercayaan merek. Hal ini disebabkan oleh kompleksnya proses pembentukan loyalitas konsumen yang biasanya memakan waktu yang cukup lama. Kepercayaan menjadi modal utama dalam hubungan jangka panjang konsumen dan merek. Maka dari itu, hasil ini menunjukkan bahwa Wardah harus memperhatikan ekspektasi serta harapan konsumen terhadap merek ini sehingga dapat memberikan klaim selaras dengan harapan konsumen tersebut. Selain itu, besarnya pengaruh karakter kebaikan dalam kepribadian merek halal terhadap kepercayaan merek menunjukkan Wardah harus lebih aktif dalam mengadakan event bertema motivasi serta lebih jeli dalam melihat aktivitas CSR yang seperti apa yang sedang dibutuhkan oleh masyarakat Indonesia saat ini. Hal ini berguna dalam perancangan strategi branding yang tepat agar konsumen tetap yakin untuk menjalin hubungan jangka panjang dengan Wardah. Simpulan penelitian ini diharapkan dapat membantu pengembangan pembentukan loyalitas konsumen di Indonesia melalui faktor agama, kepercayaan, serta nilai-nilai lain yang diyakini penting oleh masyarakat Indonesia. Hasil ini juga diharapkan dapat memberi arahan bagi pemasar, terutama bagi merek-merek lokal seperti Wardah, mengenai aplikasi branding yang sesuai dengan karakteristik konsumen Indonesia.

Keterbatasan penelitian ini ialah jumlah variabel yang dibahas sedikit, jumlah responden yang kecil, serta wilayah pengambilan responden yang cukup luas sehingga penelitian tidak menunjukkan hasil yang representatif. Oleh karena itu, penelitian selanjutnya dapat menggunakan variabel lain seperti identitas merek yang mungkin lebih besar pengaruhnya terhadap peningkatan loyalitas merek, serta diharapkan penelitian selanjutnya dapat menggunakan jumlah responden yang lebih banyak.

\section{REFERENSI}

Aaker, D. A. (1991). Managing brand equity: Capitalizing on the value of a Brand. Free Press. Abdillah, W., \& Jogiyanto. (2015). Partial least square (PLS) alternatif structural equation modeling (SEM) dalam penelitian bisnis. ANDI.

Ahmad, M. F. (2015). Antecedents of halal brand personality. Journal of Islamic Marketing, 6(2), 209- 
223. https://doi.org/10.1108/JIMA-03-2014-0023

Ahmed, M., \& Jan, M. T. (2015). An extension of Aaker's brand personality model from Islamic perspective: A conceptual study. Journal of Islamic Marketing, 6(3), 388-405. https://doi.org/10.1108/JIMA-10-2014-0068

Belk, R. W. (1988). Possessions and the extended self. Journal of Consumer Research, 15(2), 139-168. https://doi.org/10.1086/209154

Borzooei, M., \& Asgari, M. (2013). The halal brand personality and its effect on purchase intention. Interdisciplinary Journal of Contemporary Research in Business, 5(3), 481-491. https://www.researchgate.net/publication/255961895_The_Halal_brand_personality_and_its_eff ect_on_purchase_intention

Chin, W. W. (1998). The partial least squares aproach to structural equation modeling. Modern methods for business research. Lawrence Erlbaum Associates, Inc.

Delgado, B. E., \& Alemán, J. L. M. (2001). Brand trust in the context of consumer loyalty. European Journal of Marketing, 35(11/12), 1238-1258. https://doi.org/10.1108/EUM0000000006475

Delgado, E., \& Fernández, E. (2016). Once upon a brand': Storytelling practices by Spanish brands. Spanish Journal of Marketing - ESIC, 20(2), 115-131. https://doi.org/10.1016/j.sjme.2016.06.001

Ferdinand, A. (2014). Metode penelitian manajemen. Badan Penerbit Universitas Dipenogoro.

Fernandez, A. H., \& Lewis, M. C. (2019). Brand authenticity leads to perceived value and brand trust. European Journal of Management and Business Economics, 28(3), 222-238. https://doi.org/10.1108/EJMBE-10-2017-0027

Geçti, F., \& Zengin, H. (2013). The relationship between brand trust, brand affect, attitudinal loyalty and behavioral loyalty: A field study towards sports shoe consumers in Turkey. International Journal of Marketing Studies, 5(2), 111-119. https://doi.org/ 10.5539/ijms.v5n2p111

Ghozali, I. (2014). Structural equation modeling, metode alternatif dengan partial least square (PLS). Badan Penerbit Universitas Diponegoro.

Henseler, J. (2018). Partial least squares path modeling: Quo vadis? Quality \& Quantity, 52, 1-8. https://doi.org/10.1007/s11135-018-0689-6

Ismail, B. M. S. I., \& Alias, N. B. (2016). Islamic brand: A conceptual definition of brand from Islamic perspective. Journal of Islamic Studies and Culture, 4(2), 59-71. https://doi.org/10.15640/jisc.v4n2a6

Katadata. (2020). Industri halal untuk semua. https://katadata.co.id/timpublikasi katadata/analisisdata/5ea3a73811d32/industri-halal-untuk-semua

Keller, K. L. (2013). Strategic brand management: Building, measuring, and managing brand equity. Pearson Prentice Hall.

Kotler, P., \& Armstrong, G. (2009). Marketing, an introduction. Pearson Prentice Hall.

Kuleh, Y., \& Setyadi, D. (2016). The effect of brand trust and affection on the attitudinal and purchase loyalty of celluler telecomunication customers in East Kalimantan - Indonesia. European Journal $\begin{array}{llll}\text { of Business } & \text { 8nd }\end{array}$ https://www.iiste.org/Journals/index.php/EJBM/article/view/32468

Lada, S., Tanakinjal, G. H., \& Amin, H. (2009). Predicting intention to choose halal products using theory of reasoned action. International Journal of Islamic and Middle Eastern Finance and Management, 2(1), 66-76. https://doi.org/10.1108/17538390910946276

Lestari, I., Lubis, A. N., Karina, B., \& Sembiring, F. (2018). Effect and impact of brand, trust, and halal products towards switching barrier on the loyalty of Tabita cosmetic users (Case study: Students of Faculty of Economics and Business, UNPAB). Saudi Journal of Humanities and Social Sciences (SJHSS), 6256(February), 305-317. https://doi.org/10.21276/sjhss.2018.3.2.20

Lin, L. Y. (2010). The relationship of consumer personality trait, brand personality, and brand loyalty: An empirical study of toys and video games buyers. Journal of Product \& Brand Management, 19(1), 4-17. https://doi.org/10.1108/10610421011018347

Lina. (2020). Kosmetik impor menggerogoti pasar dalam negeri. Pelakubisnis.com. https://pelakubisnis.com/2020/02/kosmetik-impor-menggerogoti-pasar-dalam-negeri

Mabkhot, H. A., Shaari, H., \& Salleh, S. M. (2017). The influence of brand image and brand personality on brand loyalty, mediating by brand trust: An empirical study. Jurnal Pengurusan, 50, 71-82. https://doi.org/ 10.17576/pengurusan-2017-50-07

Malhotra, N. K. (1988). Self concept and product choice: An integrated perspective. Journal of 
Economic Psychology, 9(1), 1-28. https://doi.org/10.1016/0167-4870(88)90029-3

Melewar, T. C., Foroudi, P., Gupta, S., Kitchen, P. J., \& Foroudi, M. M. (2017). Integrating identity, strategy and communications for trust, loyalty, and commitment. European Journal of Marketing, 51(3), 572-604. https:// doi.org/10.1108/EJM-08-2015-0616

Morgan, R. M., \& Hunt, S. D. (1994). The commitment-trust theory of relationship marketing. Journal of Marketing, 58(3), 20-38. https://doi.org/10.2307/1252308

Nikhashemi, S. R., \& Valaei, N. (2018). The chain of effects from brand personality and functional congruity to stages of brand loyalty: The moderating role of gender. Asia Pacific Journal of Marketing and Logistics, 30(1), 84-105. https://doi.org/10.1108/APJML-01-2017-0016

Paragon Technology and Innovation. (2018). Wardah luncurkan "Wardah Inspiring Movement" sebagai hadiah untuk HUT Kemerdekaan Indonesia. Kontan. https://pressrelease.kontan.co.id/release/wardah-luncurkan-wardah-inspiring-movement-sebagaihadiah-untuk-hut-kemerdekaan-indonesia

Pew Research Center. (2020). Religious demography: Affiliation. http://www.globalreligiousfutures.org/countries/indonesia

Raut, U. R., Pawar, P. A., Brito, P. Q., \& Sisodia, G. S. (2019). Mediating model of brand equity and its application. Spanish Journal of Marketing-ESIC, 23(2), 295-318. https://doi.org/ 10.1108/SJME-04-2019-0021

Sánchez, R. A., Illescas, R. A., Molinillo, S., \& Lopez, F. J. M. (2020). Trust and loyalty in online brand communities. Spanish Journal of Marketing-ESIC, 24(2), 177-191. https://doi.org/10.1108/SJME01-2020-0004

Shin, S. K. S., Amenuvor, F. E., Basilisco, R., \& Antwi, K. O. (2019). Brand trust and brand loyalty: A moderation and mediation perspective. Current Journal of Applied Science and Technology, 38(4), 1-17. https://doi.org/ 10.9734/CJAST/2019/v38i430376

Tenenhaus, A., \& Vinzi. (2004). A global goodness-of-fit index for PLS structural equation modelling. Proceedings of the XLII SIS Scientific Meeting, 1, 739-774. https://www.academia.edu/17633234/A_global_Goodness_of_Fit_index_for_PLS_structural_eq uation_modelling

Tong, X., Su, J., \& Xu, Y. (2018). Brand personality and its impact on brand trust and brand commitment: An empirical study of luxury fashion brands. International Journal of Fashion Design, Technology and Education, 11(2), 196-209. https://doi.org/ 10.1080/17543266.2017.1378732

Top Brand Award. (2020). Top brand index fase 1 2020. https://www.topbrand-award.com/top-brandindex/?tbi_index $=$ Top\%20Brand\&tbi_year $=2020$

Tubagus, G. S., \& Tumbuan, W. J. F. A. (2018). The relation between brand personality and self congruence of a muslim woman cosmetics (Case study of Wardah Cosmetic). Emba, 6(4), 20182027. https://doi.org/10.35794/emba.v6i4.20931

Utari, M. D., Rahyuda, I. K., \& Giantari, I. G. A. K. (2017). Pengaruh kepribadian merek terhadap komitmen dan kepercayaan merek, serta dampaknya terhadap loyalitas merek. Matrik Jurnal Manajemen, Strategi Bisnis dan Kewirausahaan, 11(1). https://doi.org/10.24843/ MATRIK:JMBK.2017.V11.i01.p06

Zainudin, M. I., Haji, F. H., \& Othman, A. K. (2019). Halal brand personality and brand loyalty among millennial modest fashion consumers in Malaysia. Journal of Islamic Marketing, 11(6), 12771293. https://doi.org/10.1108/JIMA-10-2018-0187 